\title{
KOMENTARZ DO WYROKU SĄDU UNII EUROPEJSKIEJ W SPRAWACH POŁĄCZONYCH T-836/16 I T-624/17 RzeczPospolita Polska PRZECIWKO KOMISJI EUROPEJSKIEJ ${ }^{1}$
}

\begin{abstract}
Streszczenie. Komentowana sprawa dotyczy kwalifikacji polskiego podatku od sprzedaży detalicznej jako pomocy państwa, a analiza skupia się w niej na ocenie selektywności. Ocena tego kryterium kwalifikacji środka jako pomocy państwa w odniesieniu do środków podatkowych budzi wiele kontrowersji, których orzecznictwo Trybunału Sprawiedliwości Unii Europejskiej nie rozwiewa. Komentarz odnosi się do podstawowego, z punktu widzenia oceny selektywności środków podatkowych, pojęcia systemu odniesienia oraz zawiera analizę podatku od sprzedaży detalicznej w świetle orzeczenia w sprawie Gibraltar (w sprawach połączonych C-106/09 P i C-107/09 P).
\end{abstract}

Słowa kluczowe: pomoc państwa, selektywność, podatek od sprzedaży detalicznej w Polsce, progresywna skala stawek podatku

\section{PodateK OD SPRZEDAŻY DETALICZNeJ}

W dniu 6 lipca 2016 r. sejm polski uchwalił ustawę o podatku od sprzedaży detalicznej² o następujących cechach. Przedmiotem opodatkowania jest sprzedaż detaliczna towarów konsumentom będącym osobami

* Doktor nauk prawnych, pracuje w Komisji Europejskiej, Dyrekcji Generalnej ds. Podatków i Unii Celnej, e-mail: anna_nykiel@hotmail.com. Poglądy wyrażonew tym artykule są wyłącznie poglądami autorki i nie należy ich przypisywać Komisji Europejskiej.

1 ECLI:EU:T:2019:338.

2 Dz.U. z 2016 r., poz. 1155. 
fizycznymi. Podatnikami podatku są wszyscy sprzedawcy detaliczni. Podstawę opodatkowania stanowi osiągnięta w danym miesiącu nadwyżka przychodów ponad kwotę $17 \mathrm{mln}$ PLN. Stawki podatku wynoszą:

- $0,8 \% \mathrm{w}$ odniesieniu do miesięcznego przychodu $\mathrm{w}$ przedziale od 17 mln do 170 mln PLN,

- 1,4\% w odniesieniu do miesięcznego przychodu w przedziale przekraczającym kwotę 170 mln PLN.

\section{Postępowanie PRzed Komisją}

Komisja decyzją z 19 września 2016 r. wszczęła postępowanie przewidziane w art. 108 ust. 2 Traktatu o funkcjonowaniu Unii Europejskiej ${ }^{3}$ (TFUE) w sprawie pomocy państwa SA.44351 (2016/C) (ex 2016/NN)4. W decyzji tej Komisja nakazała władzom polskim, na podstawie art. 13 rozporządzenia proceduralnego ${ }^{5}$, niezwłoczne zawieszenie stosowania progresywnych stawek w podatku będącym przedmiotem postępowania do czasu przyjęcia przez Komisję decyzji w sprawie jego zgodności z rynkiem wewnętrznym.

Rząd polski wniósł do Sądu Unii Europejskiej (dalej: Sąd) o stwierdzenie nieważności decyzji o wszczęciu postępowania, kwestionując kwalifikację podatku od sprzedaży detalicznej jako pomocy państwa w rozumieniu art. 107 ust. 1 TFUE. Jednocześnie zawiesił stosowanie rozpatrywanego środka.

W swojej końcowej decyzji, zamykającej postępowanie w sprawie 2018/160 z dnia 30 czerwca 2017 r. w sprawie pomocy państwa SA.44351 $(2016 / C)(\text { ex 2016/NN })^{6}$, Komisja wskazała, że podatek od sprzedaży detalicznej stanowi pomoc państwa niezgodną z rynkiem wewnętrznym i że został wprowadzony w życie w sposób niezgodny z prawem.

Rząd polski wniósł do Sądu o stwierdzenie nieważności również decyzji końcowej.

3 Wersja skonsolidowana: Dz.Urz. UE z 2012 r., C 326, s. 47.

${ }^{4}$ Dz.Urz. UE z 2016 r., C 406, s. 76.

5 Rozporządzenie Rady (UE) 2015/1589 z dnia 13 lipca 2015 r. ustanawiające szczegółowe zasady stosowania art. 108 Traktatu o funkcjonowaniu Unii Europejskiej (Dz.Urz. UE z 2015 r., L 248, s. 9).

${ }^{6}$ Dz.Urz. UE z 2018 r., L 29, s. 38. 
Komisja przypomniała, że „aby móc zakwalifikować środek jako pomoc państwa, po pierwsze musi mieć miejsce interwencja państwa lub przy pomocy zasobów państwowych; po drugie interwencja musi być w stanie wpływać na wymianę handlową pomiędzy państwami członkowskimi; po trzecie środek musi przyznawać przedsiębiorstwu selektywną korzyść gospodarczą; oraz po czwarte musi on zakłócać konkurencję lub grozić jej zakłóceniem"'.

Jeżeli chodzi o kryterium pochodzenia od państwa lub z zasobów państwowych, Komisja wskazała, po pierwsze, że podatek można jednoznacznie przypisać państwu polskiemu, skoro został ustanowiony ustawą przyjętą przez Sejm. Po drugie, Komisja podkreśliła, że progresywna struktura stawek podatku od sprzedaży detalicznej prowadzi do rezygnacji przez Polskę z wpływów podatkowych, które mogłaby ona pobierać, gdyby objęła przedsiębiorstwa handlu detalicznego o niższym przychodzie taką samą średnią efektywną stawką podatku jak przedsiębiorstwa o wysokim przychodzie.

Jeżeli chodzi o istnienie korzyści, to Komisja przypomniała, za utrwalonym orzecznictwem ${ }^{8}$, że nie tylko świadczenia pozytywne, ale również różnego rodzaju środki zmniejszające obciążenia przedsiębiorstw mogą być uznane za pomoc państwa. W odniesieniu do podatku od sprzedaży detalicznej wskazała, że progresywny charakter podatku skutkuje przyznaniem korzyści sprzedawcom detalicznym o niskich przychodach. Komisja uznała też, że przedsiębiorcy działający jako franczyzobiorcy w modelu franczyzy uzyskują korzyść w porównaniu z przedsiębiorstwami o zintegrowanej strukturze dystrybucji, gdyż w pierwszym przypadku przychód dzieli się na tyle części, ilu jest franczyzobiorców, podczas gdy w drugim przypadku brany jest pod uwagę przychód w ujęciu globalnym ${ }^{9}$.

Oceniając podatek od sprzedaży detalicznej pod kątem jego selektywności, Komisja powołała się na trzystopniowy test ${ }^{10}$, zgodnie z którym, po pierwsze, należy określić system odniesienia, czyli powszechny

7 Decyzja końcowa Komisji 2018/160 (Dz.Urz. UE z 2018 r., L 29, s. 38, pkt 33).

${ }^{8}$ Sama Komisja powołała się tu na uzasadnienie wyroku w sprawie C-143/99, Adria-Wien Pipeline, ECLI:EU:C:2001:598, pkt 38.

${ }^{9}$ Decyzja końcowa Komisji, pkt 40. Zob. też uzasadnienie wyroku Sądu w sprawach połączonych T-836/16 i T-624/17, pkt 11.

10 Ibidem, pkt 41. 
lub normalny system podatkowy obowiązujący w danym państwie członkowskim. Po ustaleniu systemu odniesienia kolejny etap analizy polega na zbadaniu, czy dany środek stanowi odstępstwo od tego systemu. W tym celu konieczne jest ustalenie, czy środek może sprzyjać określonym przedsiębiorstwom $\mathrm{w}$ porównaniu $\mathrm{z}$ innymi przedsiębiorstwami, które znajdują się w podobnej sytuacji faktycznej i prawnej w świetle istotnego celu tego systemu odniesienia ${ }^{11}$. Fakt, że dany środek nie stanowi odstępstwa od systemu odniesienia, przesądza o tym, że nie można go uznać za środek selektywny. Jeżeli stanowi odstępstwo, to jest prima facie selektywny i należy ustalić, czy jest on uzasadniony charakterem lub ogólną strukturą systemu odniesienia. Jeżeli tak jest, to środek taki nie jest selektywny, a zatem nie wchodzi w zakres stosowania art. 107 ust. 1 TFUE.

Komisja uznała, że systemem odniesienia jest w rozpatrywanej sprawie opodatkowanie miesięcznych przychodów ze sprzedaży detalicznej podatkiem jednolitym (liniowym), bez włączania do systemu odniesienia progresywnej struktury stawek podatku. Stwierdziła ponadto, że progresywna struktura stawek nie stanowi części systemu odniesienia, który nie powinien też ograniczać się do przedsiębiorstw osiągających obroty powyżej $17 \mathrm{mln} \mathrm{PLN}^{12}$.

Komisja uznała następnie, że progresywne stawki polskiego podatku oraz przedziały, do których mają one zastosowanie, powodują, iż podatek od sprzedaży detalicznej w sposób dyskryminujący różnicuje sprzedawców detalicznych w zależności od poziomu osiąganych przychodów, a tym samym od ich wielkości. W rezultacie przedsiębiorstwa o wysokim przychodzie są jednocześnie objęte znacznie wyższymi stawkami krańcowymi oraz wyższymi średnimi stawkami podatku niż przedsiębiorstwa o niskim przychodzie. Podsumowując tę część rozważań, Komisja wskazała więc, że progresywna struktura stawek stanowi odstępstwo od systemu odniesienia, który zakłada opodatkowanie sprzedaży detalicznej wszystkich przedsiębiorstw prowadzących w Polsce sprzedaż detaliczną jednolitą stawką podatku (podatkiem liniowym), co sprzyja sprzedawcom detalicznym o niskich przychodach, czyli mniejszym przedsiębiorstwom. Badany środek jest zatem, zdaniem Komisji, prima facie selektywny ${ }^{13}$.

11 Zob. Zawiadomienie Komisji w sprawie pojęcia pomocy państwa w rozumieniu art. 107 ust. 1 TFUE, 2016/C 262/01 (Dz.Urz. UE z 2016 r., C 262, s. 1, pkt 135).

12 Decyzja końcowa Komisji, pkt 42-49.

13 Decyzja końcowa Komisji, pkt 54, 55. 
Komisja uznała, że odstępstwo od systemu odniesienia w postaci progresywnej struktury podatku nie jest uzasadnione charakterem lub ogólną strukturą systemu. Władze polskie wskazywały, że progresywna struktura stawek podatku od sprzedaży detalicznej jest ewentualnie ${ }^{14}$ uzasadniona ze względu na cel redystrybucyjny, tak jak w przypadku podatku od dochodu. Podnosiły ponadto, że przedsiębiorstwa osiągające wysokie przychody mają większą zdolność płatniczą i mogą korzystać z ekonomii skali, lepszych warunków dostaw i strategii podatkowych, do których mniejsze przedsiębiorstwa nie mają dostępu. Według Komisji cel redystrybucyjny nie może być realizowany za pomocą podatku od przychodów ciążącego na przedsiębiorstwach w zależności od wielkości ich działalności, bez uwzględnienia kosztów, rentowności, zdolności płatniczej lub udogodnień, z których, według władz polskich, mogą korzystać jedynie duże przedsiębiorstwa. Zdaniem Komisji progresywny podatek od przychodów mógłby być uzasadniony, gdyby wykazano, że efekty zewnętrzne wywołane przez działalność podlegającą opodatkowaniu są większe przy większych przychodach podatnika, a tak się nie stało w rozpatrywanej sprawie ${ }^{15}$.

Komisja uznała, że środek będący przedmiotem postępowania zakłóca konkurencję lub grozi jej zakłóceniem oraz wpływa na wymianę handlową wewnątrz Unii. Wskazała ona w szczególności, że rynek sprzedaży detalicznej w Polsce jest otwarty na konkurencję i podmioty z innych państw członkowskich są na nim aktywne. Podobnie sprzedawcy detaliczni mający swoją siedzibę w Polsce mogą prowadzić działalność w innych państwach członkowskich. Wobec tego wszelka pomoc na korzyść danych podmiotów gospodarczych będzie miała wpływ na wewnątrzunijną wymianę handlową ${ }^{16}$. Komisja uznała ponadto, że zwolnienie przedsiębiorstw o niskim przychodzie z podatku, który musiałyby one płacić, gdyby były objęte taką samą stawką podatku jak przedsiębiorstwa o wysokim przychodzie, stanowi pomoc operacyjną, która co do zasady zakłóca konkurencję lub grozi jej zakłóceniem, umacniając pozycję finansową przedsiębiorstw o niskim przychodzie na polskim rynku sprzedaży detalicznej ${ }^{17}$.

14 Władze polskie kwestionowały dyskryminujący charakter progresywnej struktury stawek podatku. Zob. decyzja końcowa Komisji, pkt 57.

15 Ibidem, pkt 56-60; zob. też uzasadnienie orzeczenia w komentowanej sprawie, pkt 15.

16 Decyzja końcowa Komisji, pkt 62.

17 Ibidem, pkt 63. 
Sąd nie zgodził się z oceną Komisji i stwierdził nieważność obu zaskarżonych decyzji. Uznał on, że Komisji nie udało się wykazać w zaskarżonych decyzjach istnienia selektywnej korzyści wprowadzającej zróżnicowanie wśród podmiotów gospodarczych, które w świetle celu wyznaczonego przez polskiego ustawodawcę podatkowi od sprzedaży detalicznej znajdują się w porównywalnej sytuacji faktycznej i prawnej ${ }^{18}$.

Sąd potwierdził, że dla kwalifikacji podatku od sprzedaży detalicznej jako środka pomocowego zasadnicze znaczenie ma kryterium selektywności. Powołując się na utrwalone orzecznictwo, Sąd wskazał, że uznanie korzystnego środka podatkowego za selektywny wymaga trzystopniowej analizy, do której odwołała się również Komisja, koncentrującej się na ustaleniu systemu odniesienia, istnienia odstępstwa od tego systemu oraz istnienia uzasadnienia odstępstwa charakterem i strukturą systemu ${ }^{19}$.

Sąd rozpoczął zatem swą analizę od zbadania kwestii normalnego systemu podatkowego, w odniesieniu do którego należy co do zasady rozstrzygnąć o istnieniu bądź nieistnieniu selektywnej korzyści.

\subsection{System odniesienia}

Sąd nie zgodził się z definicją systemu odniesienia przyjętą przez Komisję, zgodnie z którą w systemie tym przychody sprzedawców detalicznych są opodatkowane jednolitą stawką od pierwszej złotówki ${ }^{20}$. System taki jest, zdaniem Sądu, systemem hipotetycznym, który nie mógł zostać uwzględniony. Analizę selektywnego charakteru korzyści podatkowej należy bowiem przeprowadzić „w świetle rzeczywistych cech charakterystycznych "normalnego» systemu podatkowego, w który się ona wpisuje, zidentyfikowanych na pierwszym etapie tej metody, a nie w świetle hipotez, których nie przyjął właściwy organ”21.

Zdaniem Sądu Komisja zidentyfikowała „normalny” system, „który jest bądź niekompletny, bez stawek opodatkowania, bądź hipotetyczny, co stanowi naruszenie prawa"22.

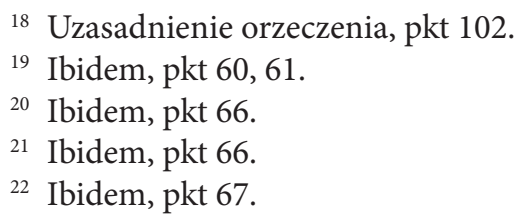


Sąd wskazał, że biorąc pod uwagę sektorowy charakter podatku od sprzedaży detalicznej, jedynym „normalnym” systemem, który mógł zostać uznany za system odniesienia, był - zgodnie ze stanowiskiem polskiego rządu - podatek od sprzedaży detalicznej sam w sobie. Struktura tego podatku obejmuje progresywną skalę stawek i przedziały tego podatku, w tym również kwotę wolną od podatku przewidzianą dla przychodów mieszczących się w przedziale od 0 do $17 \mathrm{mln}$ PLN, ponieważ kwota ta stanowi de facto część konstrukcji opodatkowania i działalność odpowiadająca tej kwocie jest objęta sektorowym zakresem stosowania podatku ${ }^{23}$.

\subsection{Dyskryminacja w świetle celu systemu odniesienia}

Stwierdziwszy, że Komisja popełniła błąd w zakresie identyfikacji systemu odniesienia, Sąd postanowił sprawdzić, czy wniosek, do którego ona doszła, nie jest uzasadniony innymi względami, które pozwoliłyby zidentyfikować istnienie selektywnej korzyści ${ }^{24}$.

Komisja uznała, że konstrukcja podatku od sprzedaży detalicznej opierająca się na stawkach progresywnych i przedziałach była sprzeczna $\mathrm{z}$ celem tego podatku i miała skutki dyskryminujące dla przedsiębiorstw z tego sektora. Jako cel podatku Komisja wskazała uzyskanie wpływów do budżetu państwa oraz opodatkowanie przychodów wszystkich przedsiębiorstw handlu detalicznego. W tym kontekście Sąd wskazał, że cel zidentyfikowany przez Komisję jest wspólny wszystkim podatkom celowym, dlatego nie jest wystarczający do ustalenia charakteru poszczególnych podatków. Sąd wskazał również, że progresywna struktura stawek podatku nie może jako taka być sprzeczna z celem pozyskiwania wpływów budżetowych ${ }^{25}$.

Sąd zgodził się w istocie ze stanowiskiem rządu polskiego, który wskazywał, że celem podatku od sprzedaży detalicznej było wprowadzenie sektorowego opodatkowania sprzedawców detalicznych, zgodnego z logiką redystrybucyjną. Komisja popełniła zatem błąd, uznając za cel podatku cel inny od tego, który wskazały władze polskie ${ }^{26}$.

Sąd podkreślił, że z ugruntowanego orzecznictwa wynika, iż niezależnie od okoliczności, czy cel podatku obejmuje wpływ na działalność przedsiębiorstw podlegających opodatkowaniu, czy korzyść dotyczy szczególnego
23 Ibidem, pkt 68 .
24 Ibidem, pkt 70.
25 Ibidem, pkt 71, 72.
26 Ibidem, pkt 76, 77. 
sektora gospodarczego, czy też korzyść jest potencjalnie dostępna dla każdego przedsiębiorstwa podlegającego opodatkowaniu, jeżeli korzyść ta prowadzi do różnic $\mathrm{w}$ traktowaniu, które są sprzeczne $\mathrm{z}$ celem podatku, ma ona charakter selektywny. „Niemniej sam cel podatku może obejmować modulację służącą rozłożeniu wysiłku fiskalnego lub ograniczeniu jego wpływu. Można także uwzględnić szczególne sytuacje, które odróżniają niektórych podatników od pozostałych, nie ignorując przy tym celu podatku"27. Istotne jest natomiast, by modulacja nie była arbitralna ${ }^{28}$.

Podsumowując tę część rozważań, Sąd wskazał, że „w przypadku podatku od przychodów kryterium modulacji, które przybiera formę progresywnego opodatkowania od określonego, nawet wysokiego, progu i które może odpowiadać woli, by obejmować opodatkowaniem działalność przedsiębiorstwa tylko wtedy, gdy działalność ta osiąga pewne znaczenie, nie implikuje samo w sobie istnienia selektywnej korzyści”29. Komisja nie mogła zatem wywieść istnienia selektywnej korzyści z samej tylko progresywnej struktury stawek podatku ${ }^{30}$. Mimo powyższego Sąd wskazał, że „gdyby jednak Komisja wykazała w zaskarżonych decyzjach, że konkretnie przyjęta progresywna struktura opodatkowania została ustalona w sposób, który sprawia, że cel danego podatku staje się w znacznym stopniu bezprzedmiotowy, można by uznać, że korzyść, jaką mogą z tego czerpać przedsiębiorstwa korzystające z zerowego lub niewielkiego opodatkowania w porównaniu z innymi przedsiębiorstwami, jest selektywna" ${ }^{31}$. Sąd zauważył jednak, że w zaskarżonych decyzjach Komisja ograniczyła się do uznania, iż to sama zasada progresywnego opodatkowania powoduje powstanie selektywnej korzyści, co stanowi naruszenie prawa ${ }^{32}$.

Sąd odniósł się również do stwierdzenia Komisji, iż rzeczywista średnia stawka podatku i stawka krańcowa opodatkowania przedsiębiorstw różniły się w zależności od ich przychodów. Sąd wskazał, że takie zróżnicowanie rzeczywistej średniej stawki i stawki krańcowej w zależności od wysokości podstawy opodatkowania jest immanentnie związane z każdym systemem opodatkowania o progresywnej strukturze ${ }^{33}$.

\footnotetext{
27 Ibidem, pkt 83.

28 Ibidem, pkt 91.

29 Ibidem, pkt 92.

30 Ibidem, pkt 93.

31 Ibidem, pkt 94.

32 Ibidem, pkt 96.

33 Ibidem, pkt 99.
} 
W zaskarżonych decyzjach Komisja odniosła się ponadto do okoliczności, że de facto podatek od sprzedaży detalicznej obciąża w większym stopniu zagraniczne przedsiębiorstwa niż polskie przedsiębiorstwa oraz że obciąża on w większym stopniu sieci dystrybucji zorganizowane w sposób zintegrowany niż sieci dystrybucji oparte na modelu franczyzy. W odniesieniu do pierwszej z tych okoliczności Sąd stwierdził, że sama Komisja przypomniała na rozprawie, iż jeśli chodzi o wykazanie selektywności korzyści spowodowanych strukturą stawek tego podatku, zaskarżone decyzje nie są oparte na stwierdzeniu dyskryminacji ze względu na krajowe pochodzenie podatników. Rząd polski w swoich skargach wskazał, czego Komisja nie zakwestionowała, że posługiwanie się modelem franczyzy jest praktykowane w Polsce zarówno przez zagraniczne sieci dystrybucji, jak i przez polskie sieci dystrybucji. Sąd zaznaczył również, że sytuacja sklepu franczyzowego różni się od sytuacji sklepu zintegrowanego. Pierwszy z nich jest bowiem autonomiczny co do zasady zarówno pod względem prawnym, jak i pod względem finansowym od swojego franczyzodawcy, co nie ma miejsca w przypadku sklepu zintegrowanego w stosunku do przedsiębiorstwa, które go kontroluje w ramach sieci dystrybucji ${ }^{34}$.

Podsumowując swoje rozważania, Sąd stwierdził, że Komisji nie udało się wykazać w zaskarżonych decyzjach istnienia selektywnej korzyści wprowadzającej zróżnicowanie wśród podmiotów gospodarczych, które w świetle celu wyznaczonego przez polskiego ustawodawcę podatkowi od sprzedaży detalicznej znajdują się w porównywalnej sytuacji faktycznej i prawnej. Błędy, jakie Komisja popełniła co do definicji „normalnego” systemu podatkowego, co do celu tego podatku i co do oceny selektywności, nie pozwoliły jej sprawdzić, w świetle celu rozpatrywanego podatku, czy konkretnie przyjęta progresywna struktura prowadziła do traktowania w różny sposób przedsiębiorstw znajdujących się w porównywalnej sytuacji faktycznej i prawnej ${ }^{35}$.

\section{Komentarz}

Komentowana sprawa dotyczy kwalifikacji polskiego podatku od sprzedaży detalicznej jako pomocy państwa, a analiza skupia się w niej na ocenie selektywności. Ocena tego kryterium kwalifikacji środka jako

\footnotetext{
34 Ibidem, pkt 100, 101.

35 Ibidem, pkt 102.
} 
pomocy państwa w odniesieniu do środków podatkowych budzi wiele kontrowersji, których orzecznictwo Trybunału Sprawiedliwości Unii Europejskiej nie rozwiewa ${ }^{36}$.

\subsection{System odniesienia}

Pewnej systematyzacji i podsumowania orzecznictwa w zakresie sposobu oceny selektywności środków podatkowych spróbowała dokonać Komisja w swoim Zawiadomieniu w sprawie pojęcia pomocy państwa w rozumieniu art. 107 ust. 1 TFUE ${ }^{37}$. Komisja wskazała w nim na konieczność przeprowadzenia trzyetapowej analizy, do której w sprawie będącej przedmiotem komentarza odniosła się i ona, i Sąd. Dla prawidłowego przeprowadzenia tej analizy właściwa identyfikacja systemu odniesienia ma fundamentalne znaczenie. Sama Komisja wyjaśniła pojęcie systemu odniesienia w następujący sposób:

System odniesienia obejmuje spójny zbiór zasad, które zwykle mają zastosowanie - na podstawie obiektywnych kryteriów - do wszystkich przedsiębiorstw wchodzących w jego zakres, jak określono przez cel tego systemu. Zasady te zazwyczaj definiują nie tylko zakres tego systemu, ale także warunki, na jakich system ten ma zastosowanie, prawa i obowiązki przedsiębiorstw podlegających temu systemowi oraz aspekty techniczne dotyczące funkcjonowania systemu. Jeżeli chodzi o podatki, system odniesienia opiera się na takich elementach, jak podstawa opodatkowania, podatnicy, zdarzenie podatkowe i stawki podatkowe ${ }^{38}$.

Identyfikacja systemu odniesienia jest łatwa, gdy mamy do czynienia ze zbiorem szczególnych zasad w ramach ogólnego systemu jakiegoś podatku, np. podatku dochodowego od osób prawnych. W przypadku podatków skierowanych na osiągnięcie określonych celów systemem odniesienia jest natomiast co do zasady sam ten podatek ${ }^{39}$. Stawia to pod znakiem zapytania przydatność modelu trzystopniowej oceny selektywności w odniesieniu do

${ }^{36} \mathrm{Na}$ ten temat zob. podobnie J.L. Buendía Sierra, Finding selectivity or the art of comparison, „European State Aid Law Quarterly” 2018, nr 1, s. 85.

37 Dz.Urz. UE z 2016 r., C 262, s. 1, pkt 126 i n. Na ten temat zob. też A. Nykiel-Mateo, J. Wiemann, Selectivity, [w:] EU Competition Law, t. 4: State Aid, Book one, Deventer-Leuven 2016, s. 263.

38 Pkt 133, 134 Zawiadomienia.

39 Zob. wyrok Sądu z dnia 7 marca 2012 r. w sprawie T-210/02, RENV British Aggregates Association przeciwko Komisji, ECLI:EU:T:2012:110, pkt 49 i 50, oraz Zawiadomienie Komisji w sprawie pojęcia pomocy państwa w rozumieniu art. 107 ust. 1 TFUE, pkt 134. 
tych podatków, kiedy przedmiotem oceny z punktu widzenia selektywności jest właśnie dany podatek sam w sobie.

W komentowanej sprawie mamy do czynienia właśnie $\mathrm{z}$ takim szczególnym podatkiem, który powinien zostać uznany za system odniesienia. Zgodnie z Zawiadomieniem Komisji w sprawie pojęcia pomocy państwa elementy składające się na ten system to:

- podatnicy - wszyscy sprzedawcy detaliczni,

- zdarzenie podatkowe - przedmiot opodatkowania - sprzedaż detaliczna towarów konsumentom będącym osobami fizycznymi,

- podstawa opodatkowania - osiągnięta w danym miesiącu nadwyżka przychodów ponad kwotę $17 \mathrm{mln}$ PLN,

- stawki podatku:

- $0,8 \% \mathrm{w}$ odniesieniu do miesięcznego przychodu w przedziale od 17 mln do 170 mln PLN,

- 1,4\% w odniesieniu do miesięcznego przychodu w przedziale przekraczającym kwotę 170 mln PLN.

Jak wskazywano wyżej, zdaniem Komisji systemem odniesienia powinien być natomiast system, w którym przychody sprzedawców detalicznych są opodatkowane jednolitą stawką od pierwszej złotówki. Jej zdaniem progresywna struktura stawek nie stanowi części systemu odniesienia, który nie powinien ograniczać się do przedsiębiorstw osiągających przychody powyżej $17 \mathrm{mln}$ PLN $^{40}$.

Należy zatem w pełni zgodzić się z oceną Sądu, że przedstawiona wyżej charakterystyka systemu odniesienia jest w omawianej sprawie nieprawidłowa, gdyż dotyczy ona bądź systemu hipotetycznego, nieistniejącego w rzeczywistości, bądź niekompletnego, nieobejmującego stawek opodatkowania.

\subsection{Ocena podatku od sprzedaży detalicznej w świetle orzeczenia w sprawie Gibraltar}

Wydaje się, że sama Komisja przyznaje w swoim Zawiadomieniu w sprawie pojęcia pomocy państwa, iż w pewnych przypadkach przeprowadzanie trzystopniowej analizy w celu ustalenia selektywności danego środka nie ma sensu. Powołując się na wyrok TSUE w sprawie Gibraltar $^{41}$ i nawiązując do

40 Decyzja końcowa Komisji, pkt 42-49.

${ }^{41}$ Wyrok TSUE z dnia 15 listopada 2011 r. w sprawach połączonych C-106/09 P i C-107/09 P, Komisja i Hiszpania przeciwko Rządowi Gibraltaru i Zjednoczonemu Królestwu, ECLI:EU:C:2011:732. 
orzeczenia w sprawie Ferring ${ }^{42}$, Komisja wskazuje, że zwłaszcza w odniesieniu do szczególnych opłat, skierowanych na osiągnięcie określonego celu gospodarczego, społecznego czy politycznego, konieczna może być weryfikacja, czy granice opłaty wyznaczono w sposób wyraźnie arbitralny lub stronniczy, tak aby sprzyjać określonym produktom lub określonym rodzajom działalności, które znajdują się w porównywalnej sytuacji pod względem logiki leżącej u podstaw opłat będących przedmiotem oceny ${ }^{43}$.

W świetle powyższego niektórzy autorzy, np. J.L. Buendía Sierra, uważają, że w przypadku podatków szczególnych, służących osiągnięciu określonych celów, analiza selektywności powinna się skupiać na ustaleniu, czy dany środek wprowadza rozróżnienie między podmiotami gospodarczymi, które, w świetle celów systemu podatkowego w danym państwie członkowskim, znajdują się w podobnej sytuacji faktycznej i prawnej ${ }^{44}$. Analiza Trybunału w sprawie $A G N E D^{45}$, dotyczącej regionalnego podatku od dużych powierzchni handlowych, skupia się właśnie na ustaleniu istnienia takiego rozróżnienia. W swoim orzeczeniu w tej sprawie Trybunał uznał, że rozpatrywany podatek został ustanowiony w celu wspierania ochrony środowiska i zagospodarowania przestrzennego, a jego pobór miał na celu skorygowanie i zrekompensowanie skutków, jakie ma dla środowiska naturalnego i ładu przestrzennego prowadzenie działalności przez wielkopowierzchniowe obiekty handlowe. Trybunał wskazał, że nie można zakwestionować tego, iż wpływ, jaki jest wywierany przez obiekty handlowe na środowisko, zależy w znacznej mierze od ich rozmiarów. Im większa jest powierzchnia sprzedaży, tym większy jest napływ klientów, co znajduje odbicie w zwiększonym negatywnym wpływie na środowisko naturalne. Trybunał uznał również za oczywiste to, że otwarcie takich placówek stanowi, niezależnie od tego, gdzie są one położone, szczególne wyzwanie w kategoriach zagospodarowania przestrzennego. Wobec tego Trybunał doszedł do wniosku, że kryterium obciążenia podatkiem oparte na powierzchni

${ }^{42}$ Wyrok TSUE z dnia 22 listopada 2001 r. w sprawie C-53/00, Ferring, ECLI:EU: C:2001:627.

43 Zob. Zawiadomienie Komisji w sprawie pojęcia pomocy państwa w rozumieniu art. 107 ust. 1 TFUE, pkt 134.

${ }^{4}$ J.L. Buendía Sierra, Finding selectivity..., s. 88; zob. też wyrok TSUE z dnia 8 września 2011 r. w sprawach połączonych od C-78/08 do C-80/08, Paint Graphos i in., ECLI:EU:C:2011:550, pkt 49.

45 Wyrok TSUE z dnia 26 kwietnia 2018 r. w sprawie C-233/16, ANGED, ECLI:EU:C:2018:280; na ten temat zob. J.J. Piernas López, Revisiting some fundamentals of fiscal selectivity: The ANGED case, „European State Aid Law Quarterly” 2018, nr 2, s. 274. 
sprzedaży wprowadza rozróżnienie pomiędzy kategoriami przedsiębiorstw prowadzących obiekty, które z punktu widzenia celów realizowanych przez ustawodawstwo ustalające to kryterium nie znajdują się w sytuacjach porównywalnych ${ }^{46}$.

Należy tu podkreślić, co zauważa także sam J.L. Buendía Sierra ${ }^{47}$, że test porównywalności (comparability test) nie został określony w orzecznictwie w jasny sposób. W sprawie Paint Graphos TSUE odniósł się do celów systemu podatkowego $\mathrm{w}$ danym państwie członkowskim ${ }^{48}$, ale $\mathrm{w}$ innych orzeczeniach, np. w sprawie British Aggregates ${ }^{49}$, Trybunał odniósł się do celów badanego środka. Wskazówka, że należy ustalić, czy dany środek nie skutkuje różnym traktowaniem podmiotów, które w kontekście celów tego środka znajdują się w zbliżonej sytuacji faktycznej lub prawnej, brzmi ryzykownie i nie jest pomocna, zwłaszcza gdy celem danego środka jest właśnie uprzywilejowanie określonych przedsiębiorstw lub produkcji określonych towarów.

Komisja uznała, że polski podatek od sprzedaży detalicznej został skonstruowany w taki sposób, aby sprzyjać określonym przedsiębiorstwom - sprzedawcom detalicznym o niższych przychodach i sprzedawcom detalicznym działającym w modelu franczyzy albo niezależnie, a był niekorzystny dla sprzedawców detalicznych o wyższych dochodach oraz dla sieci sprzedawców działających w modelu holdingowym. Struktura ta nie znajduje, zdaniem Komisji, uzasadnienia w celu tego podatku, którym jest opodatkowanie wszystkich przedsiębiorstw handlu detalicznego ${ }^{50}$.

Jak wskazano wyżej, Sąd nie zgodził się z oceną Komisji, odrzucając w szczególności jej wnioski co do celu podatku od sprzedaży detalicznej. Sąd przyjął, za rządem polskim, że celem podatku od sprzedaży detalicznej było wprowadzenie sektorowego opodatkowania sprzedawców detalicznych, zgodnego z logiką redystrybucyjną.

$\mathrm{Z}$ argumentacją Sądu trudno się nie zgodzić, zwłaszcza tam, gdzie wskazuje on, że progresywne struktury opodatkowania, w tym te obejmujące istotne kwoty wolne od podatku, nie implikują same w sobie istnienia

46 Wyrok TSUE w sprawie C-233/16, ANGED, pkt 52-55.

${ }^{47}$ J.L. Buendía Sierra, Finding selectivity..., s. 89.

48 Wyrok TSUE z dnia 8 września 2011 r. w sprawach połączonych od C-78/08 do C-80/08, Paint Graphos i in., pkt 49.

${ }^{49}$ Wyrok w sprawie C-487/06P, British Aggregates przeciwko Komisji, ECLI:EU: C:2008:757, pkt 79 i n.

50 Decyzja końcowa Komisji, pkt 49. 
elementów pomocy państwa. Jak zauważył Sąd, sama Komisja w pkt 139 Zawiadomienia w sprawie pojęcia pomocy państwa zaznaczyła, że progresywny charakter podatku dochodowego może być uzasadniony jego celem redystrybucyjnym. Sąd słusznie stwierdził, że - wbrew stanowisku Komisji - nic nie pozwala ograniczyć tego rodzaju oceny do podatków dochodowych $^{51}$. Komisja nie mogła zatem wywieść selektywnego charakteru podatku od sprzedaży detalicznej z samej tylko progresywnej struktury stawek tego podatku ${ }^{52}$. Takie samo stanowisko Sąd zajął w wydanym nieco ponad miesiąc później wyroku w sprawie węgierskiego podatku od reklam o progresywnej strukturze stawek ${ }^{53}$.

Trudno również nie zgodzić się z oceną Sądu, że Komisja nie wykazała istnienia selektywności de facto ani dyskryminującego traktowania przedsiębiorstw zagranicznych i sieci dystrybucji zorganizowanych w sposób zintegrowany $^{54}$. Sama Komisja przyznała zresztą, że jej decyzje nie były oparte na stwierdzeniu dyskryminacji ze względu na krajowe pochodzenie podatników. Sąd zwrócił także uwagę na to, co wskazywał rząd polski, że posługiwanie się modelem franczyzy jest praktykowane w Polsce zarówno przez zagraniczne, jak i polskie sieci dystrybucji oraz że sytuacja sklepu franczyzowego różni się od sytuacji sklepu zintegrowanego pod względem finansowym i prawnym ${ }^{55}$.

\section{Podsumowanie}

Mimo że wydane ostatnio orzeczenia Sądu pokazały, iż w sprawach pomocy podatkowej kontrowersje mogą skupiać się wokół ustalenia istnienia korzyści ${ }^{56}$, selektywność pozostaje centralnym punktem oceny w przypadku wielu środków o charakterze fiskalnym ${ }^{57}$. Kryterium to

51 Uzasadnienie orzeczenia, pkt 91.

${ }^{52}$ Ibidem, pkt 93.

${ }^{53}$ Wyrok w sprawie T-20/17, Wegry przeciwko Komisji, ECLI:EU:T:2019:448, pkt 80-105.

${ }^{54}$ Ibidem, pkt 99-101.

${ }^{55}$ Ibidem, pkt 101.

56 Zob. wyroki Sądu z dnia 24 września 2019 r. w sprawach T-760/15, Holandia przeciwko Komisji i T-636/16, Starbucks i Starbucks Manufacturing Emea przeciwko Komisji, ECLI:EU:T:2019:669 oraz w sprawach T-755/15, Luksemburg przeciwko Komisji i T-759/15, Fiat Chrysler Finance Europe przeciwko Komisji, ECLI:EU:T:2019:670.

${ }^{57} \mathrm{Na}$ ten temat zob. K. Bacon, State Aids and General Measures, Yearbook of European Law 1997, s. 269; A. Nykiel-Mateo, Pomoc państwa a ogólne środki interwencji w europejskim prawie wspólnotowym, Warszawa 2009, s. 184 i n.; A. Nykiel-Mateo, J. Wiemann, 
Trybunał Sprawiedliwości Unii Europejskiej interpretuje w sposób bardzo szeroki, co wyraźnie widać w orzeczeniach takich jak to w sprawie Gibraltar, dzięki czemu Komisji stosunkowo łatwo jest wykazać spełnienie tego kryterium i, w konsekwencji, istnienie pomocy państwa ${ }^{58}$. Kryterium selektywności musi mieć jednak granice nie tylko ze względu na konieczność zapewnienia pewności prawa, ale także po to, aby uniknąć sytuacji, w których Komisji będzie się zarzucać realizację celów politycznych za pośrednictwem narzędzi wynikających z jej kompetencji w zakresie kontroli pomocy.

W komentowanym wyroku Sąd nie zgodził się z oceną selektywności podatku od sprzedaży detalicznej zastosowaną przez Komisję. Uznał on, że nie można przyjmować za system odniesienia systemu niekompletnego lub hipotetycznego. Sąd nie zgodził się również z arbitralnym określeniem celu podatku, odbiegającym od celu wskazanego w uzasadnieniu do projektu ustawy o podatku od sprzedaży detalicznej oraz w stanowisku władz polskich, które wskazywały, że celem było ustanowienie podatku sektorowego zgodnego z zasadą redystrybucji podatkowej ${ }^{59}$. Sąd podjął zatem próbę nakreślenia granic kryterium selektywności oraz, pośrednio, ograniczenia ingerencji Komisji w odniesieniu do środków podatkowych stosowanych przez państwa członkowskie. Osiągnięcie równowagi pomiędzy ochroną konkurencji na rynku wewnętrznym a ochroną kompetencji państw członkowskich w sprawach podatkowych pozostanie jednak jeszcze długo wyzwaniem dla orzecznictwa.

Komisja odwołała się od komentowanego orzeczenia Sądu ${ }^{60}$. Było to łatwe do przewidzenia, gdyż TSUE wielokrotnie już odrzucał restrykcyjną interpretację kryterium selektywności zastosowaną przez Sąd i sam przyjął

Selectivity, s. 263 i n.; T. Jaeger, From Santander to LuxLeaks - and Back, „European State Aid Law Quarterly" 2015, nr 3, s. 345; T. Iliopoulos, The state aid cases of Starbucks and Fiat: New routes for the concept of selectivity?, „European State Aid Law Quarterly” 2017, nr 2, s. 263; P. Nicolaides, Excessive widening of the concept of selectivity, „European State Aid Law Quarterly” 2017, nr 1, s. 62.

${ }^{58} \mathrm{Na}$ ten temat zob. L. Panci, Latest developments on the interpretation of the concept of selectivity in the field of corporate taxation, „European State Aid Law Quarterly” 2018, nr 3, s. 353.

59 Uzasadnienie orzeczenia, pkt 73.

60 Zob. http://curia.europa.eu/juris/document/document.jsf?text=\&docid=218454 \&pageIndex $=0 \&$ doclang $=$ PL\&mode $=$ req $\&$ dir $=\& o c c=$ first $\&$ part $=1 \&$ cid $=1187011 \mathrm{w}$ wer sji z 7.10.2019 r. 
szeroką wykładnię tego kryterium ${ }^{61}$, która pozwoliła na rozszerzenie granic kontroli środków podatkowych na podstawie przepisów o pomocy państwa. Ta rozbieżność między liniami orzeczniczymi Sądu i Trybunału pokazuje jak trudną sprawą jest kwalifikacja środków podatkowych z punktu widzenia przepisów o pomocy państwa. Jest ona też w pewnym sensie dowodem na bezradność orzecznictwa w zakresie wyznaczenia granic pojęcia pomocy państwa o charakterze podatkowym, pojęcia, które w ujęciu orzecznictwa samego Trybunału ma być przecież pojęciem „obiektywnym”.

\section{Bibliografia}

Bacon K., State aids and general measures, Yearbook of European Law 1997.

Buendía Sierra J.L., Finding selectivity or the art of comparison, „European State Aid Law Quarterly" 2018, nr 1.

Iliopoulos T., The state aid cases of Starbucks and Fiat: New routes for the concept of selectivity?, „European State Aid Law Quarterly” 2017, nr 2.

Jaeger T., From Santander to LuxLeaks - and Back, „European State Aid Law Quarterly” 2015, nr 3.

Nicolaides P., Excessive widening of the concept of selectivity, „European State Aid Law Quarterly" 2017, nr 1.

Nykiel-Mateo A., Pomoc państwa a ogólne środki interwencji w europejskim prawie wspólnotowym, Warszawa 2009.

Nykiel-Mateo A., Wiemann J., Selectivity, [w:] EU Competition Law, t. 4: State Aid, Book One, red. N. Pesaresi, K. Van de Casteele, L. Flynn, C. Siaterli, Deventer-Leuven 2016.

Panci L., Latest developments on the interpretation of the concept of selectivity in the field of corporate taxation, „European State Aid Law Quarterly” 2018, nr 3.

Piernas López J.J., Revisiting some fundamentals of fiscal selectivity: The ANGED case, „European State Aid Law Quarterly” 2018, nr 2.

61 Zob. np. orzeczenia w sprawach T-210/02, British Aggregates Association przeciwko Komisji, ECLI:EU:T:2014:65; C-487/06P, British Aggregates Association przeciwko Komisji, ECLI:EU:C:2008:757, oraz w sprawach połączonych T-211/04 i 215/04 Government of Gibraltar i Zjednoczone Królestwo przeciwko Komisji, ECLI:EU:T:2008:595, i w sprawach połączonych C106/09 P i C107/09 P, Komisja i Królestwo Hiszpanii przeciwko Government of Gibraltar i Zjednoczone Królestwo, ECLI:EU:C:2011:732; zob. też L. Panci, Latest Developments..., s. 361 . 
Annotation on the Judgment in Joined Cases

T-836/16 and T-624/17 Republic of Poland v European Commission

Summary. The commented case concerns qualification of the Polish tax on the retail sector as State aid with the analysis of the General Court focusing on selectivity of the measure. The assessment of selectivity of fiscal measures is often controversial and the case law of the Court of Justice of the European Union does not really clarify the matter. The annotation refers to the notion of the system of reference - key to the analysis of selectivity of fiscal measures and analyses the retail sales tax in the context of the Gibraltar judgment (joined cases C-106/09 P and C-107/09 P).

Keywords: state aid, selectivity, Polish tax on the retail sector, progressive structure of tax rates 